(C) 2018. This manuscript version is made available under the CC-BY-NC-ND 4.0 license http://creativecommons.org/ licenses/by-nc-nd/4.0/

\title{
Investor sentiment and advertising expenditure
}

Mian, M. and Sharma, P. and Gul, F.

\begin{abstract}
A strategic issue facing marketing managers is 'how much and when' to spend on advertising. We argue that investor sentiment in the stock market may influence advertising expenditure by affecting firms' ability to raise new funds. We show that during periods of low (high) investor sentiment, firms decrease (increase) their advertising expenditure, even though the effectiveness of advertising is greater (lower) during such periods. We also find that these results are stronger for financially constrained firms that rely more on external financing. Our findings suggest that marketing managers can improve the efficiency of their advertising expenditure by raising (reducing) it during periods of low (high) sentiment.
\end{abstract}

Keywords: Advertising expenditure; affordability method; marketing expenditure; investor sentiment; stock market; advertising effectiveness. 


\section{Introduction}

The extant marketing literature often recognizes the importance of 'affordability' in determining the advertising budgets of firms, whereby managers spend more on advertising when they have greater funds at their disposal and less when they are short of money ${ }^{1}$ (e.g., Joseph \& Richardson, 2002; Tellis, 1998). An important strand of this literature links the notion of affordability to broad macroeconomic factors and examine how economic recessions influence the levels of advertising expenditure (e.g., Deleersnyder et al. 2009; Frankenberger \& Graham, 2003; Srinivasan et al., 2005) as well as its effectiveness in terms of firm-level outcomes such as profits and market share (Steenkamp \& Fang 2011, Srinivasan et al. 2011). However, there is hardly any research on how the conditions in the stock markets may impact the availability of funds for the firms, and hence, their advertising expenditure. We address this gap by studying the influence of investor sentiment in the stock market on advertising expenditure.

By using investor sentiment, we look beyond the effects of macro-economic variables such as state of the economy, because the concept of investor sentiment relates to conditions in financial markets and depicts broad waves of investor optimism and pessimism in the stock market, which do not always overlap with the economic cycles of recession, contraction, or expansion. This also allows us to extend the aforementioned notion of 'affordability' by emphasizing the availability of external funds to managers. In doing so we integrate and extend the research on factors influencing advertising expenditure, including the state of the economy and the availability of funds.

\footnotetext{
${ }^{1}$ Advertising budgets are also derived using 'percentage-of-sales' and 'competitive-parity' methods (see, for example, Blasko \& Patti, 1984; Patti \& Blasko, 1981), which are discussed later in the paper.
} 
The finance literature has long recognized that besides internally generated earnings, a firm's access to external funds (e.g., by issuing new shares in the stock market or taking a new bank loan) is an important source of funds available to managers for investment (Chirinko \& Schaller, 2001; Polk \& Sapienza, 2009; Shleifer, 2003). Access to external funds, in turn, depends on conditions in the financial markets, which vary considerably over time. In the midst of the Internet bubble of 1998-99, for example, many young technology firms had little internal cash flows yet they were flush with resources as stock market investors were keen to invest in such firms. Conversely, during the financial crisis of 2008-9, many companies had trouble financing their urgent investment needs, even though they were profitable, simply due to problems in the banking sector and stock market (e.g., Desperately Seeking a Cash Cure, The Economist (November 20, 2008), and Cutting Costs, The Economist (December 24, 2008). Conditions in the financial market therefore have an important bearing on the availability of funds for firms.

We focus on the burgeoning literature in finance, which argues that financial markets experience broad waves of investor optimism and pessimism, labelled as investor sentiment (Baker \& Wurgler, 2006, 2007). Such changes in sentiment cause significant variations over time in investors' perceptions about firms' future prospects. During periods of high sentiment, investors are excessively optimistic about the future and overestimate the expected cash flows and/or underestimate the risk, resulting in an overvaluation of stocks. This overvaluation and increased investor appetite for risk makes it easier and attractive for managers to use the stock market to raise new funds for their firms' investment needs. The converse happens during periods of low sentiment, when investors are excessively pessimistic about the future. They systematically underestimate the expected cash flows and/or overestimate risk, causing an undervaluation of stocks. This undervaluation and investors' heightened aversion to risk make it difficult for managers to obtain new funds from investors (Luo, Jiang, \& Cai, 2014). 
This is especially true for financially constrained firms — that is, firms that have low or negative internal cash flows and face substantial uncertainty about their future prospectswhose access to external finances may dry up dramatically during low sentiment periods.

Indeed, managers' ability to raise new funds from the stock market is so closely linked to the prevailing sentiment in the stock market that the most common measure of investor sentiment in the recent literature, the Baker and Wurgler sentiment index (or BW index), uses the number of initial public offerings (IPO) and the first day return on these IPOs as important inputs to compute the index (Baker \& Wurgler, 2006, 2007). Hence, by default, periods when the BW sentiment index is low (high) are those when managers find it difficult (easy) to access new funds from the stock market. The affordability method of advertising budgeting would, therefore, predict that the level of advertising expenditure is systematically lower (higher) during periods of low (high) investor sentiment.

Advertising expenditure may be especially prone to funding constraints because unlike spending on equipment or setting up of a factory, it is often viewed as discretionary, arguably because its payoffs are relatively uncertain and accrue over longer periods (Erickson \& Jacobson, 1992; Mizik, 2010; Mizik \& Jacobson, 2007). We therefore hypothesize that managers would spend less on advertising (as a percentage of sales) during periods of low sentiment than during periods of high sentiment. This would be especially true for financially constrained firms because they depend to a greater extent on external financing and it becomes especially difficult for them to raise funds during low sentiment periods, compared to firms with lower financial constraints (Baker, Stein, \& Wurgler, 2003).

To test these hypotheses, we employ Baker and Wurgler’s (2006, 2007) market-wide investor sentiment index and examine how advertising levels vary with sentiment. We study all firms in the COMPUSTAT dataset with listed stocks during 1971-2010. Our results show 
that the firms in our sample spend significantly less on advertising, on average, during periods of low investor sentiment than during periods of high sentiment. These results hold after we explicitly control for the effect of macroeconomic variables, such as recessions and consumer sentiment, as well as industry- and firm-level variables that depict firms’ growth prospects. Using two popular measures of financial constraints, we also find that the positive association between sentiment and advertising is stronger for financially constrained firms that must rely more on external funding for their investment needs. We also provide additional empirical evidence to justify our key premise that external financing is a significant component for a typical firm in our sample. We also show that advertising expenditure tends to be positively associated with external financing, especially for financially constrained firms. Finally, firms tend to raise more external funds during high sentiment periods, especially those that are financially constrained.

Allowing investor sentiment to influence advertising expenditure may lead to lower advertising efficiency because changes in investor sentiment over time do not correlate perfectly with product market considerations and consumer sentiment. For example, the advertising budget may be sub-optimal when periods of low investor sentiment coincide with periods of high consumer sentiment. During such periods, expectations of higher future consumer demand and considerations of competitive parity may dictate increasing the advertising; yet managers may be forced to cut down on advertising due to the limited availability of funds. Moreover, because firms in aggregate would spend less (more) on advertising during low (high) sentiment periods, advertising may be more (less) effective during such periods due to lower (greater) clutter and cheaper (expensive) rates by broadcasting channels. Therefore, it is likely that the effectiveness of advertising expenditure is higher (lower) in low (high) sentiment periods. While it is easy to measure advertising expenditure, there is little consensus on how to measure advertising effectiveness (Fischer \& 
Himme, 2016; Simon, 1984; Soberman, 2009). We measure advertising effectiveness by the elasticity of profits to advertising (e.g., Kamber, 2002; Srinivasan et al., 2011). We find that advertising is indeed more effective during low (vs. high) sentiment periods.

We contribute to the marketing literature in several ways. First, we provide insights for managers on how collective advertising budgets vary systematically over time and how perceptive managers who 'buck the trend' can benefit from such time variation. For example, because most companies decrease their budgets during low sentiment periods, there is less competitive clutter and better consumer recognition in the market, allowing some companies to get more mileage from their advertising. Conversely, because most companies increase their advertising budgets during high sentiment periods, some managers may find it useful to channel some of the advertising budget to other marketing activities.

Second, our study extends the ongoing research endeavors that explore the links between macroeconomic variables and time-variation in the level or effectiveness of advertising expenditure (e.g., Srinivasan et al., 2011; Steenkamp \& Fang, 2011) by examining the effect of financial market conditions on firms' marketing decisions. Together, these studies provide useful insights on how market-wide factors cause variations in firms' advertising expenditures over time. Third, by linking investor sentiment in the stock market with firms' advertising expenditures, we help integrate the latest insights in the behavioral finance literature with issues of interest to marketing professionals and academicians. Finally, our findings suggest that the notion of 'affordability of funds' in the marketing literature need to be extended to include access to ‘external' funds available to a firm.

The rest of the paper proceeds as follows. We first review the related finance literature on investor sentiment in the stock market and then develop our hypotheses. Next, we describe our data, measures, and methodology, followed by our empirical findings. Finally, we 
conclude the paper by discussing the conceptual and practical implications of our findings, and their limitations.

\section{Theoretical background and hypotheses}

\subsection{Investor sentiment, stock market valuations, and corporate decisions}

The classical view in finance, often called 'efficient markets hypothesis', leaves little room for investor psychology to influence markets (e.g., Fama, 1970). According to this view, the market prices of financial assets, such as stocks, reflect the discounted present value of the expected future cash flows. If prices ever move away from this correct valuation benchmark, smart investors or arbitrageurs move in and trade aggressively, pushing prices back to their correct valuation. In sharp contrast to this classical view, however, a burgeoning literature in behavioral finance argues that investor psychology can and does play a significant role in financial markets, in general, and the stock market in particular (Barberis \& Thaler, 2003; Shiller, 2003). This literature not only discusses a number of cognitive errors that investors make when trading in the stock market, but also identifies the factors that limit the ability of smart arbitrageurs to correct the effect of such errors on the market.

A strand of the behavioral finance literature examines the effect of broad market-wide waves of investor optimism and pessimism, or investor sentiment, on the stock market (e.g., Baker \& Wurgler, 2007). It defines investor sentiment broadly as ‘beliefs about future cash flows or discount rates that are not supported by the prevailing economic fundamentals' (Baker \& Wurgler, 2006, 2007), and constructs indexes of investor sentiment in the stock market by combining information contained in several metrics of investor exuberance after purging the effects of macroeconomic fundamentals (Baker \& Wurgler, 2006; Lemmon \& Portniaguina, 2006). Studies in this line of research not only provide empirical evidence that validates the proxies of investor sentiment as measures of investor optimism and pessimism, 
but also show that investor sentiment causes over- and under-pricing of stocks in the stock market. These studies also demonstrate that the effect of sentiment is distinct from that of macroeconomic variables.

Sentiment-driven mispricing in the stock market also has significant effects on managerial investment decisions (Baker \& Wurgler, 2012; Dong, 2010; Gervais, 2010; Polk \& Sapienza, 2009). When stock market valuations are high (low) in high (low) sentiment periods, managers tend to over- (under-) invest (Chirinko \& Schaller, 2001; Lamont \& Stein, 2006; McLean \& Zhao, 2014). In bullish times when their stock is overpriced and investors are ready to provide them with capital at very low cost, mangers invest more and finance the new investments by issuing new shares at inflated prices (Lamont \& Stein, 2006; Polk \& Sapienza, 2009; Shleifer \& Vishny, 2003). Conversely, when sentiment is low and the stock is underpriced, new funding is prohibitively expensive and managers tend to significantly reduce their investments (Stein, 1996; Baker, Stein, \& Wurgler, 2003).

\subsection{Determinants of advertising expenditure}

Early research on advertising expenditure identifies 'affordability', 'percentage-of-sales' and 'competitive-parity’ as the most common methods by which firms decide their advertising budgets (Blasko \& Patti, 1984; Patti \& Blasko, 1981). Subsequent studies show that none of these methods may be optimal and as a result, most firms end up overspending on advertising (Aaker \& Carman, 1982; Lodish, et al., 1995). Among all these methods, ‘affordability’ seems quite popular because it allows firms to spend on advertising what they can afford. Under this method, firms with greater resources may spend more on advertising than what is necessary or desirable, and conversely, firms with little resources may underspend on advertising (Joseph \& Richardson, 2002). The main reason why marketing managers may prefer this method to others is the inherent uncertainty about the exact effect 
of advertising on sales. It is also suggested that allocating a part of the discretionary budget to advertising is like purchasing insurance, and it makes sense to buy more insurance when the firm has access to greater cash at a lower cost of capital (Joseph \& Richardson, 2002).

In contrast, in ‘competitive-parity’ approach firms benchmark their advertising budgets against the advertising expenditure of their competitors in the same industry (Dean, 1951; Lee, 1994; Mitchell, 1993; Prasad \& Sethi, 2004). For example, firms may decide to spend a percentage of the total competitive advertising expenditure in an industry that is equal to its share of the market, referred to as 'share of voice' (Jones, 1990). The advocates of this approach argue that the total advertising spend and its allocation to all the competitors in an industry represents their combined wisdom. However, it assumes that the competitors know what they are doing and that they all share the same goals as each other, which is generally not true and may lead to inefficient decisions (Lilien, Kotler, \& Moorthy, 1992). Prior research also identifies other drivers of advertising expenditure, such as changes in advertising strategy and/or creative approach, and profit contribution goals or other financial targets (Belch et al., 2008; Prendergast, West \& Shi, 2006).

Overall, prior research shows that firms use a variety of heuristics to decide their advertising budgets, even though many of them may not involve strictly 'rational' decisions. There is also a growing realization that marketing managers do not always use complex methods to arrive at their advertising budgets (Batra, 2009). An extensive review of marketing literature over six decades suggests that advertising decisions are usually not derived from rigorous empirical generalizations (Rasmussen, 1952; Rossiter, 2012). Moreover, there is still limited research on the 'external' or 'environmental' factors that could influence marketing managers' decisions about advertising expenditure (Albers, 2012; Hanssens et al., 2016; Martín-Herrán et al., 2012). 


\subsection{Investor sentiment and advertising expenditure}

As pointed out earlier, it is well accepted in the behavioral finance literature that firms' access to new capital varies significantly with investor sentiment, wherein firms find it relatively easier to raise new funds in high sentiment periods and face serious funding constraints during low sentiment periods. In fact, Baker and Wurgler (2006) construct their sentiment index using variables such as the number of initial public offerings (IPOs) and the first day return on the IPOs, which reflect the ease with which firms can raise new funds for their investments. The affordability argument would, therefore, suggest that periods of high sentiment are associated with higher expenditure on advertising. The converse would be true for low sentiment periods, when firms are short of funds and are forced to curtail their advertising budgets (Joseph \& Richardson, 2002; Luo et al., 2014; Tellis, 1998).

Marketing expenditure may be especially prone to sentiment-related changes in access to external funds because advertising may be viewed as discretionary, and its contribution to sales and earnings may not be readily visible (Srinivasan \& Hanssens, 2009). Furthermore, the marketing benefits may accrue over several quarters or even years (Steenkamp \& Fang, 2011). The behavioral finance literature argues that the effect of managerial incentives is the most pronounced in settings where the quality of managers' actions is difficult to evaluate and the feedback is noisy (Gervais, 2010). Marketing expenditure appears to fit this description well. Based on the above, we state our first hypothesis as follows:

H1: Firms spend less on advertising (as a percentage of sales) during periods of low investor sentiment than during periods of high sentiment.

It is instructive to reiterate and clarify that $\mathrm{HI}$ is underpinned by three premises: (i) external finance, such as new stock or bond issues or new borrowing from banks, is an important component of total funds available to a firm; (ii) a firm's advertising budget is 
positively associated with the availability of external funds; and (iii) firms can raise external funds more easily during high sentiment periods than during low sentiment periods. In a later section, we provide empirical support for each of these three premises.

\subsection{Moderating effects of firm attributes}

If time varying access to external funds indeed underpins the relation we hypothesize in H1, we should find that it is more pronounced when firms are financially constrained. A firm is perceived as financially constrained if it has low or negative internal cash flows and finds it difficult to fund its investment needs at a given point in time. Such firms typically have high uncertainty and volatility, which makes it difficult for them to raise external funds (Whited \& Wu, 2006, Hadlock \& Pierce, 2010). Their investment budgets are more likely to depend on the conditions prevailing in the financial markets for two reasons. First, due to limited internal funds, these firms may rely more on external sources to fund their investment needs (Stein, 1996, Baker, Stein, \& Wurgler, 2003). Second, because they tend to be more volatile and risky, investors' willingness to invest in them may vary more with conditions in the financial markets (Baker \& Wurgler, 2012).

When investor sentiment in the stock market is high, investors' risk aversion decreases. They become willing to invest in firms with limited internal cash flows and that appear volatile and risky. This happens not only because investors are willing to take the risks associated with these companies, but also because they may perceive that these companies have greater growth prospects. Such firms therefore find it easier to raise new capital during periods of high sentiment (Baker \& Wurgler, 2012). In contrast, when sentiment is low, investors' risk aversion increases. They have limited appetite for investing in firms with weak internal cash flows and that appear risky and volatile. This makes it very difficult for such

firms to raise money for their operations (see, for example, Desperately Seeking a Cash Cure, 
The Economist (November 20, 2008), and Cutting Costs, The Economist (December 24, 2008). In sum, because financially constrained firms may have to rely more on external funds to finance their advertising budgets, and because their ability to raise external funds varies more with sentiment, their advertising budgets would be more prone to changes in investor sentiment than other firms. ${ }^{2}$ We, therefore, predict a stronger positive association between advertising and investor sentiment for financially constrained firms than for other firms. ${ }^{3}$

H2: The effect of investor sentiment on advertising expenditure is stronger when firms are financially more constrained.

\section{Research methodology}

\subsection{Data}

We obtain data on firms' annual advertising expenditure from COMPUSTAT. The primary source of the COMPUSTAT data is the publically disclosed accounting statements of firms. The data coverage is sparse before 1971, so our sample period ranges from 1971 to 2010 and covers a large number of companies across a broad set of industries. Prior to 1994, accounting regulations in the US required listed commercial and industrial firms to make public a ‘Supplementary Income Statement Information' schedule that included information about advertising. In December 1993, Accounting Standards Executive Committee (AcSEC) issued a new rule SOP 93-7, which made it optional for companies to report their advertising expenditure. This rule, which became effective from June 15, 1994, also curtailed firms'

\footnotetext{
${ }^{2}$ In a later section, we provide empirical evidence for these two premises. Specifically, we show that (i) the advertising budgets of financially constrained firms have a stronger positive association with external financing, and (ii) the external financing of such firms is more strongly associated with sentiment.

${ }^{3}$ As we discuss later, we employ two indices popular in the finance literature- the WW index and SA indexto measure firms' financial constraints.
} 
latitude in terms of how they report their advertising expenditure and increased the uniformity of the reported expenses across firms. Nevertheless, the dataset covers a large number of companies across a broad set of industries.

We merge the advertising and accounting data from COMPUSTAT with the stock price and returns information from the Centre for Research on Security Prices (CRSP). We retain firms with common shares listed on US stock exchanges and remove specialized firms such as closed-end mutual funds, American Depository Receipts, and real estate investment trusts from our analysis. We retain only those firms that report a positive value for advertising expenditure in our analysis. We also remove a tiny number of firms that report negative net sales. We further remove observations for which we do not have complete data for all of the control variables and measures of financial constraints. Our final sample includes 54,209 firm-year observations covering 1971-2010. The number of unique firms in our sample is 8,201. Figure 1 reports the number of firms in our sample by year, which is typically about 1,400 firms per year. The dip in the number of firms in 1994 is due to the change in regulation noted above, whereby the reporting of advertising became voluntary.

$<$ Insert Figure 1 about here $>$

Next, we explain some of our key measures and variables in detail. Appendix A provides a complete list of all the variables used in our study.

\subsubsection{Measures of investor sentiment and economic conditions}

We employ Baker and Wurgler’s $(2006,2007)$ investor sentiment index in our analysis. ${ }^{4}$ Baker and Wurgler (2006, 2007) describe how the index is constructed and validated. The BW index is a composite measure that combines six individual proxies of investor sentiment,

\footnotetext{
${ }^{4}$ We thank Jeffrey Wurgler for making the index available on his web site http://people.stern.nyu.edu/jwurgler/. Every few years, the index is updated to include a more recent period.
} 
namely closed-end fund discount, NYSE share turnover, number of IPOs, first day returns on IPOs, share of equity issues in total debt and equity issues, and dividend premium (the log difference of the average market-to-book ratio of payers and non-payers). To isolate investor sentiment from economic fundamentals, each of these six proxies is first regressed on five macroeconomic variables: the growth in industrial production index (Federal Reserve Statistical Release G.17); growth in consumer durables, nondurables, and services (all from BEA National Income Accounts Table 2.10); and a dummy variable for NBER recessions. The first principal component of the residuals of these six regressions constitutes the investor sentiment index, standardized to yield a mean of zero and a standard deviation of one. Positive values signify periods of high (i.e., bullish) sentiment and negative values periods of low (i.e., bearish) sentiment. Baker and Wurgler (2006, 2007) show that their sentiment index coincides well with anecdotal accounts of investor exuberance and panic. The index has since been widely used to examine the implications of broad waves of market-wide sentiment for financial markets (Hribar \& Mcinnis, 2012; Mian \& Sankaraguruswamy, 2012; Stambaugh, Yu, \& Yuan, 2012, 2015; Yu \& Yuan, 2011).

Before proceeding with our main analyses, we first examine the overlap between the investor sentiment index and the measure of macroeconomic performance used in Steenkamp and Fang (2011). We closely follow the procedure in Steenkamp and Fang (2011) to construct their measure of economic recessions, Contr, which is based on the filter and the cyclical component of GDP (Hodrick \& Prescott, 1997). Specifically, Contr takes the value of zero when the economy is growing at or above its long-term trend, but equals the magnitude of the decline in the cyclical component of GDP when the economy is in recession. We find that investor sentiment has a negligible correlation of 0.002 with the Steenkamp and Fang measure. This is reassuring because it suggests that we are indeed investigating a phenomenon that is empirically distinct and perhaps more novel than their measure. 
It is also useful to compare and contrast the BW measure of investor sentiment with measures of consumer sentiment. To highlight the conceptual and empirical differences between investor sentiment and consumer sentiment, we us the University of Michigan index of consumer sentiment (ICS), which is one of the most widely used measures of consumer sentiment in the US. While the ICS focusses on near-term consumer attitudes on the business climate, personal finance, and spending, the BW investor sentiment index depicts the optimism or pessimism, or risk aversion, of investors in the stock market. In contrast to consumer sentiment, which is based on telephone interviews of US households, investor sentiment is constructed based on data generated within the stock market. Empirically, we confirm the distinct nature of consumer sentiment by collecting its data over our sample period of 1971-2010. ICS is now available on a monthly frequency, but it was available on a quarterly basis before 1978. We therefore use its quarterly observations over our entire sample period, and take the average of the four calendar quarters to compute the average value of the index for a year. We then compute the correlation between the annual observations of ICS and investor sentiment. The correlation is 0.22 , as reported in Table 1 . To confirm that the effect of investor sentiment on advertising that we document is distinct from any effect of an economic recession and consumer sentiment on advertising, we include both Contr and ICS in our regressions as controls.

$<$ Insert Table 1 about here $>$

\subsubsection{Measure of advertising intensity}

To investigate how advertising expenditure varies with investor sentiment in the stock market, it would be inappropriate to look at just the dollar amount of advertising expenditure because sentiment could relate to firms' revenues, which, in turn, could influence the dollar 
amount firms spend on advertising. We obtain our measure of a firm's advertising intensity by dividing the firm's advertising expenditure with its (average) sales revenue, as follows.

$$
\text { Advertising Intensity }_{t}=\frac{\text { Advertising }_{t}}{\left(\frac{\text { Sales }_{t-1}+\text { Sales }_{t}}{2}\right)}
$$

\subsubsection{Measures of financial constraints}

We employ two popular composite measures of firm-level financial constraints from the recent literature: the WW index and SA index. Whited and Wu (2006) developed the WW index of constraints using an Euler equation approach from a structural model of investment. Their index relies on six different factors to estimate the financial constraints a firm faces: cash flows, dividends on preferred and common stock, book value of assets, the firm's own sales growth, the ratio of long term debt to total assets, and the growth of sales in the industry. The index loads negatively on the first four factors and positively on the last two. A higher value of the index for a firm signifies that the firm has higher financial constraints, and must rely more on external funds for new investments. Specifically, the index is computed for each firm in each year using the inputs and their relative weights specified in Whited and Wu (2006, Equation 13) as follows:

WWIndex $_{t}=-0.091 \mathrm{CF}_{t}-0.062$ DIVPOS $_{t}+0.021 \mathrm{LTD}_{t}-0.044 T \mathrm{~A}_{t}+0.102$ ISG $_{t}-0.035 \mathrm{SG}_{t}$

The second measure—SA index-is developed more recently by Hadlock and Pierce (2010). They first gather detailed qualitative information on financial constraints from statements made by managers in financial filings, and use this to categorize firms in terms of financial constraints. Using these derived financial constrained categories, they then estimate ordered logit models to extract the quantitative firm variables that help identify the constraints. They find that a combination of three simple factors (assets, assets squared, and 
the number of years since a firm first appears in the COMPUSTAT dataset) works reasonably well, and better than many more elaborate indices, in identifying firms with financial constraints. We follow Hadlock and Pierce (2010), and compute the SA index for each firm in each year based on the inputs and the relative weights as in Column (2) of Table 6 (p. 1928):

$$
\text { SAIndex }_{t}=-0.737 A T A_{t}+0.043 A T A_{t}^{2}-0.040 A g e_{t}
$$

The explanatory variables include ATA, the log of total assets adjusted for inflation, and Age, which is the number of years since a firm first appeared in COMPUSTAT dataset. The SA index loads negatively on assets and age, and positively on the square of assets. It is worth noting that Whited and Wu (2006) and Hadlock and Pierce (2010) do not find industry association to be marginally informative about financial constraints of firms once other variables are taken into account. ${ }^{5}$ Moreover, the correlation of the aggregated yearly values of WW index and SA index with investor sentiment is $0.074(p$-value $=0.65)$ and $0.058(p$-value $=0.72$ ), respectively. These low correlations are not surprising because the financial constraint indices are based on fundamental accounting variables whereas investor sentiment is constructed after purging the effect of the fundamentals.

\subsubsection{Summary statistics}

Table 2 reports the summary statistics of our variables. Panel A reports the statistics for the sentiment and macroeconomic variables that are available at yearly frequency. The statistics are consistent with those reported in prior studies. The investor sentiment index by construction has a mean close to zero, and a standard deviation close to one. Contr has a median of zero, consistent with the evidence in Steenkamp and Fang (2011), suggesting that

\footnotetext{
${ }^{5}$ No prior evidence exists on whether the weights of the inputs in WW and SA indices are generalizable across countries. This is, however, not a concern for us as we use the indices for the same country for which they were developed, that is, for the US market.
} 
fewer than one year in two experience economic contraction in the US. ICS, which is one of our important control variables, has a mean of 85, consistent with the numbers reported in Lemmon and Portniaguina (2006).

$<$ Insert Table 2 about here $>$

We use winsorized variables in all our analyses. Panel B reports the statistics for the firm and industry level variables based on pooled firm-year observations. All variables in Panel B are winsorized at $1 \%$ and $99 \%$ by replacing all values above (below) the $99^{\text {th }}\left(1^{\text {st }}\right)$ percentile of the respective pooled firm-year distribution with the value of the $99^{\text {th }}\left(1^{\text {st }}\right)$ percentile to mitigate the effect of extreme and/or erroneous observations on the regression estimates. The mean and standard deviation of the annual advertising expenditure (as a percentage of average sales) is $3.5 \%$ and $4.8 \%$, respectively, for the firms in our sample. The firms included in our sample on average spend $7.3 \%$ of their sales on capital expenditure and $4.3 \%$ on R\&D.

\subsection{Model specification}

To investigate the association between investor sentiment and advertising intensity, we estimate a model similar to Chakravarty and Grewal (2011). Specifically, we regress a firm's advertising expenditure (scaled by average sales) on the prevailing investor sentiment in the stock market, as follows:

$$
\begin{aligned}
& \ln \left(\text { Advertising Intensity }_{i, t}\right. \\
& \quad=a_{0}+a_{1} \ln (\text { Advertising Intensity })_{i, t-1}+b_{1} \operatorname{Sent}_{t}+b_{2} \operatorname{Sent}_{t} x F C_{i, t} \\
&+b_{3} F C_{i, t}+b_{4} \text { Contr }_{t}+b_{5} \text { Contr }_{t} x F C_{i, t}+b_{6} \text { ICS }_{t}+b_{7} \text { ICS }_{t} x F C_{i, t} \\
&+c_{1} \text { Herf }_{i, t}+c_{2} \text { IndGrowt }_{i, t}+c_{3}\left(\frac{\text { Capex }_{\text {Sales }}}{\text { Ind }_{i, t}}+c_{4} \ln \left(1+\frac{R \& D}{\text { Sales }}\right)_{i, t}\right. \\
&+ \text { Firm Fixed Effects }+\epsilon_{i, t}
\end{aligned}
$$


The subscripts $i$ and $t$ in the model signify firm and year, respectively. We use the (natural) log-transformed values of advertising intensity as the dependent variable because the distribution of advertising intensity is positively skewed. ${ }^{6}$ We include the lagged value of the dependent variable as an explanatory variable to account for the inertia in the advertising expenditure of firms. To test Hypothesis 1 , the key coefficient of interest is $b_{1}$, which captures the effect of contemporaneous investor sentiment, Sent, on advertising budgets. The hypothesis predicts this coefficient to be positive and significant. To test Hypothesis 2, we include FC as a measure of a firm's financial constraints. It alternately takes the values of WW index and SA index, the two composite measures of financial constraints that we discuss earlier. According to Hypothesis 2, the coefficient $b_{2}$ on the interaction term Sent x FC should be positive, indicating that the positive association between sentiment and advertising intensity is more pronounced for financially constrained firms.

We estimate the model in Equation (4) using pooled firm-year data with firm fixed effects. The inclusion of firm fixed effects controls for any time-invariant firm characteristics that may be relevant to advertising intensity, but that we do not include in our specification. The $t$-statistics we report are robust to the presence of heteroscedasticity. They are also based on standard errors clustered by year, to control for the time-specific correlations in advertising budgets across firms (Petersen, 2009). ${ }^{7}$

\footnotetext{
${ }^{6}$ We also experiment with two alternative specifications of Equation (4) to check the robustness of our inferences. First, to mitigate the concern about simultaneity bias, we use one-period lagged values of the explanatory variables on the right-hand side. Second, to examine the effect of scaling by sales of our firm-level variables, we estimate the model using unscaled variables. In this formulation, we use natural log of the dollar amount of advertising as the dependent variable, and include firm sales as an additional control. We find that our inferences are robust to using these alternative specifications.

${ }^{7}$ Simple OLS estimations compute standard errors under the assumption that all observations are independent. However, this assumption is frequently violated in panel data estimations and the process of clustering adjusts the standard errors and the $t$-statistics, for violation of this assumption. In our context, clustering by year is meant to correct the $t$-statistics for correlation in advertising expenditures across firms within a given year.
} 
We use Contr and ICS as control variables to account for economic recessions and consumer sentiment respectively in view of their importance as discussed earlier in the paper. Because the effect of economic recession and consumer sentiment on advertising may also differ for financially constrained firms, we also interact these variables with FC and include these as additional controls in the model. Herf is the Herfindahl-Hirschman index, a common measure of market concentration and competition in the firm's industry. We compute it using sales of firms within a two-digit Standard Industry Classification (SIC) code. We include it because the degree of competition can influence firms’ advertising spending.

To control for the possibility that firms’ growth prospects could vary over time with sentiment, we further include a few industry- and firm-level variables. We include growth rate of sales from year $t-1$ to year $t$ for all the firms in the industry the firm belongs to, where we define industry by the two-digit SIC code. We also include capital expenditure scaled by average sales, Capex, as another proxy for a firm’s growth prospects because firms with greater growth opportunities would invest more in their fixed assets, and also because new investments in fixed assets may necessitate additional advertising. Finally, we include research and development $(\mathrm{R} \& \mathrm{D})$ expenditure as a control variable because new product developments can affect the advertising budgets of firms.

\section{Main results and robustness checks}

\subsection{Main results}

We begin our analysis by examining the association between advertising intensity and sentiment in a simple bivariate setting. We do so by first computing the average value for advertising intensity for each year based on the data available for all firms during that year. This yields a time series of advertising intensity with 40 observations—one for each year in our sample period of 1971-2010. The simple correlation between the annual time series of 
advertising intensity and sentiment reported in Table 1 is 0.35 , which seems substantial. We also report the correlations between advertising and the two macro variables in Table 1. Consistent with the findings of Steenkamp and Fang (2011) that advertising expenditure reduces during recession, the correlation between advertising and their (inverse) measure of economic recession is 0.34 . Advertising is also positively correlated with consumer sentiment indicating that firms spend more on advertising when they expect their customers to increase their purchases in the near future.

We also divide our sample periods into periods of high and low sentiment and examine the average advertising intensity across these periods. Because the BW sentiment index has a mean of zero by construction, it is common in prior studies to use the zero cutoff to divide the sample years into periods of high or low sentiment (Stambaugh, Yu, \& Yuan, 2012, 2015). Values of the index greater than zero signify periods of high sentiment, whereas values below zero represent periods of low sentiment. In Table 3, we report the average advertising intensity based on pooled firm-year observations across high and low sentiment periods. The average advertising intensity is 3.2\% during low sentiment periods and increases to $3.8 \%$ during periods of high sentiment. This represents an increase of about $19 \%[=(3.8 \%-3.2 \%) /$ 3.2\%)] which again appears substantial.

$<$ Insert Table 3 about here >

When we examine the relationship between investor sentiment and advertising expenditure in a multiple regression framework using Equation (4), we obtain consistent results in Table 4. When we estimate the model without financial constraints and its interaction terms in Column 1, the coefficient on the key variable, Sent, is 0.017 ( $t$-statistic $=$ 2.72), confirming the robust positive relation between investor sentiment and firms' 
advertising intensity. ${ }^{8}$ Table 4 therefore shows that the results continue to support Hypothesis 1 when we control for other factors that affect the level of firms' advertising intensity.

\section{$<$ Insert Table 4 about here $>$}

It is also instructive to note the coefficients of some of the control variables in Column (1) of Table 4. The coefficient on ICS, which measures consumer sentiment, is positive and statistically significant, suggesting that firms increase their advertising in anticipation of consumers increasing their purchases. The significant positive coefficients on industry growth (IndGrowth) indicates that firms increase advertising when their industry is growing. The positive and highly significant coefficients on Capex and R\&D indicate that firms spend more on advertising when they expand the scale of their operations and when they engage in greater product innovation, respectively. All the coefficients on the control variables are consistent with prior literature and intuition.

To test H2, we estimate the complete model of Equation (4), in which we interact indicator variable for financial constraints, FC, with investor sentiment and other macro variables. The last two columns in Table 4 report these results. The effect of financial constraints on the relationship between investor sentiment and advertising intensity is depicted by the coefficients on the interaction variable Sent x FC in Columns (2) and (3). In Column (2), we measure the $F C$ variable through the $W W$ index and in Column (3) by the $S A$ index. According to H2, the coefficients should be positive. The results provide strong support for H2, as the coefficients are indeed positive and statistically significant. The coefficient on the stand alone variable for financial constraints, $F C$, is positive in both

\footnotetext{
${ }^{8}$ In a robustness check, we explore whether lagged sentiment has any marginal effect on advertising in the presence of its contemporaneous value. The results indicate that it is not because the lagged value of sentiment shows up as non-significant.
} 
Columns (2) and (3) and is marginally significant at $10 \%$ level in the latter column. A positive coefficient suggests that managers spend more on advertising when their resources decline in the hope of reviving them. To summarize, Table 4 indicates strong support for both H1 and H2. Firms' advertising intensity seems to be positively associated with the investor sentiment prevailing in the stock market. This association is stronger for firms that are financially constrained, consistent with the idea that these firms depend more on the availability of external funds to finance their advertising budgets.

\subsection{Endogeneity concerns and robustness checks}

A possible concern about the empirical relationship between advertising and investor sentiment relates to endogeneity, especially the problem of omitted variables. Specifically, despite the inclusion of a host of macro, industry and firm-level variables as controls in our model, it is possible that the observed relationship between sentiment and advertising simply arises due to some other variable-which we do not include in our main model in Equation (4)—driving both sentiment and advertising. We address this concern in several ways.

First, we specify our model in Equation (4) in a way that helps us mitigate this issue. In arriving at the specification of our model, we conduct a formal Hausman test to examine the presence of fixed versus random effects in our model. The Chi-Square statistic turns out to be very large ( $p<0.000)$, which clearly rejects the null of random effects, and suggests the need to include firm fixed effects. We therefore, include firm fixed effects in the model. Inclusion of firm fixed effects accounts for any permanent differences in the advertising policies of firms, and allows us to examine how over-time changes in sentiment relate to over-time changes in advertising. In addition, we include lagged values of the dependent variable in our model. This further controls for any omitted variables that affect the advertising expenditure equally in both years, $t$ and $t-1$. 
Second, to rule out the remaining possibility that some time-varying factor may be causing endogeneity, we conduct the standard Hausman-Wu test of endogeneity (Davidson and MacKinnon 1993; Baum et al. 2003). Specifically, we test whether sentiment (Sent) in Equation (4) is independent from the contemporaneous random events, i.e., the error term $\varepsilon_{i, t}$. We implement the test using the specification in Column (1) of Table 4, and use instruments that are lagged one period beyond the error term. The results indicate that F-statistic is not significant at conventional level $\left(F_{1,41562}\right)=3.09$, $p$-value $\left.>0.05\right)$. We therefore conclude that the null hypothesis — that sentiment is exogenous — cannot be rejected, and hence no explicit correction for endogeneity is required in our model.

Finally, we note that the measure of advertising intensity, specified in Equation (1), is obtained by dividing advertising expenditure by the average sales of the contemporaneous and lagged years. It is possible that managers set advertising budgets based on planned sales and not based on current or lagged sales, and expected sales are higher during period of high sentiment. If so, it is possible that the positive association between advertising and sentiment reported in Table 4 arises spuriously due to a positive association between future sales and sentiment. To rule out this possibility, we conduct additional analysis. Specifically, we compute a revised measure of advertising intensity by dividing the advertising spend with future sales. That is, we divide the advertising expenditure in year $t$ with sales in year $t+1$ (and in further robustness check, with sales in year $t+2$ ). We then examine the association between this revised measure of advertising intensity and sentiment.

If the previously documented relationship between sentiment and advertising simply arises because managers set advertising budgets based on expectations of higher future sales following periods of high sentiment, then the new measure of advertising intensity should not vary over time with investor sentiment. This is because the new measure scales, or deflates, advertising using future sales. In untabulated analysis, we re-run our main regression model 
in Table 4 by replacing its dependent variable with the revised measure of advertising intensity. The results mirror those reported in Table 4, with a positive and highly statistically significant coefficient for Sent, so the revised measure of advertising intensity exhibits almost the same level of strong positive association with sentiment as our primary measure. This suggests that the advertising-sentiment relation that we report does not spuriously emerge because we ignore the relation between current advertising and future sales. To summarize, our analyses in this section suggests that endogeneity may not be a significant concern about the observed relationship between sentiment and advertising expenditure.

\section{Additional analyses}

\subsection{Empirical validity of key premises underlying our hypotheses}

While our main results in Table 4 provide support for our two hypotheses, it would also be instructive to separately examine the empirical validity of the three premises that underpin HI. As noted earlier, these premises include the following: (i) external financing is a key source of funds for most companies, (ii) a firm's advertising budget in a year is positively associated with the external financing it receives during the year, and (iii) more external financing becomes available during periods of high sentiment than those with low sentiment.

The empirical support for the first premise appears in Table 2, where we report the summary statistics of the external financing that firms receive each year. We compute the amount of external financing based on information from financial statements available through COMPUSTAT. Specifically, we determine the external financing of a firm in year $t$ by taking the change in total assets from year t-1 to $t$, and subtracting from it the change in retained earnings over the same period. This definition encompasses all types of external financing, including net new stock issue, net new bond issues, short- and long-term borrowing from banks, and so on. We scale external financing by average sales in year t-1 
and t to make it comparable to the other firm-level variables we report, such as cash flows and advertising. We report the summary statistics of firms' external financing in our sample for 1971 to 2010. The mean is around 24\%, which is greater than the mean of the annual internal cash flows that firms generate, which is close to zero. We compute internal cash flows as income before extraordinary items plus depreciation and amortization, scaled by average sales. The amount of external financing in a year also appears significant compared to the annual capital expenditure of $7.3 \%$ and annual advertising expenditure of $3.5 \%$.

We test our second premise about the positive association between advertising expenditure of a firm and the external financing it obtains using a specification similar to that in Equation (4), as follows:

$$
\begin{aligned}
& \ln (\text { Advertising Intensity })_{i, t} \\
& =a_{0}+a_{1} \ln (\text { Advertising Intensity })_{i, t-1}+b_{1} \text { ExFin }_{t}+b_{2} \text { ExFin }_{t} x F C_{i, t} \\
& +b_{3} F C_{i, t}+c_{1} \operatorname{Herf}_{i, t}+c_{2} \text { IndGrowth }_{i, t}+c_{3}\left(\frac{\text { Capex }}{\text { Sales }}\right)_{i, t} \\
& +c_{4} \ln \left(1+\frac{R \& D}{\text { Sales }}\right)_{i, t}+\text { Firm Fixed Effects }+\epsilon_{i, t}
\end{aligned}
$$

In this specification, we replace the market-wide variables-investor sentiment, economic recession, and consumer sentiment—with a firm-specific variable, ExFin, which measures the external financing the firm raises in year $t$. We continue to include other firm-level controls and firm fixed effects in the model. ${ }^{9}$ We report the estimates from Equation (5) in Table 5. The estimated coefficient on external financing is positive and highly statistically significant at $0.072(t$-statistic $=7.63)$. This indicates that a firm's advertising expense is

\footnotetext{
${ }^{9}$ We do not include macro factors (i.e., Sent, Contr and ICS) in Equation 5 is because external financing is itself a function of these external factors, as depicted in our later analysis in Equation (6). Putting these macro factors in Equation 5 would lead to multicollinearity problem and would not allow us to obtain an unbiased estimate of the coefficients $b_{1}$ and $b_{2}$.
} 
positively associated with the external financing it raises in the year. Interestingly, the additional results in Columns (2) and (3) suggest that this positive association is stronger for firms that face financial constraints (as the significant positive coefficients on the interaction variables ExFin x WWIndex in Column (2) and ExFin x SAIndex in Column (3) show). This is consistent with the idea that firms rely more on external financing for their advertising expenditure when they face more constrains in terms of internal financial resources.

\section{$<$ Insert Table 5 about here $>$}

Finally, we examine the association between external financing and investor sentiment by running the following regression.

$$
\begin{aligned}
\text { ExFin }_{i, t}=a_{0} & +b_{1} \text { Sent }_{t}+b_{2} \text { Sent }_{t} x F C_{i, t}+b_{3} F_{i, t}+b_{4} \text { Contr }_{t}+b_{5} \text { Contr }_{t} x F C_{i, t} \\
& +b_{6} \text { ICS }_{t}+b_{7} \text { ICS }_{t} x F C_{i, t}+c_{1} \text { Herf }_{i, t}+c_{2} \text { IndGrowth }_{i, t}+c_{3}\left(\frac{\text { Capex }_{\text {Sales }}}{{ }_{i, t}}\right. \\
& +c_{4} \ln \left(1+\frac{R \& D}{\text { Sales }}\right)_{i, t}+\text { Firm Fixed Effects }+\epsilon_{i, t}
\end{aligned}
$$

The coefficient on Sent in this equation captures the association between external financing and sentiment. We report the results of estimating Equation (6) in Table 6. The coefficient on stand-alone Sent is positive in all columns, though it is statistically significant only in the last column. A positive coefficient indicates that firms raise more external fund during periods of high sentiment. Interestingly though, the results in Columns (2) and (3) suggest that this positive association is stronger for firms that face financial constraints (as the significant positive coefficients on the interaction variables ExFin x WWIndex in Column (2) and ExFin x SAIndex in Column (3) show). Thus, financially constrained firms raise especially more external financing during periods of high sentiment. Taken together, these three additional pieces of evidence support the building blocks that underpin our hypotheses. 
$<$ Insert Table 6 about here $>$

\subsection{Association between sentiment and advertising effectiveness}

If managers increase or decrease advertising budgets with sentiment due to changes in the availability of funds, then the effectiveness of adverting may also vary with sentiment. For example, Steenkamp and Fang (2011) show that changes in advertising linked to recessionrelated funding constraints increases the effectiveness of advertising during recessions. During periods of low sentiment, when firms have difficulty raising external funds, managers may be forced to pick only those marketing investments that yield the highest payoffs and leave out the other more marginal investments. During high sentiment periods, in contrast, raising money would not only be easy, but it would be available at favorable terms, relieving managers of the need to prioritize their advertising needs.

The effectiveness of advertising for individual firms could also vary across periods of high and low sentiment due to the aggregate behavior of the firms. Because most firms spend less (more) on advertising during low (high) sentiment periods, this would lead to advertising by individual firms to be more (less) effective during such periods due to lower (greater) clutter and cheaper (expensive) rates by broadcasting channels. Therefore, the effectiveness of advertising expenditure is likely to be greater during periods of low sentiment than during periods of high sentiment. To explore this possibility, we examine the association between investor sentiment and the effectiveness of advertising for firms in our sample, by measuring how the effectiveness of advertising varies with sentiment using the following model.

$$
\begin{aligned}
\ln (\text { Operating } & \text { Income })_{i, t+1} \\
& =a_{0}+b_{1} \ln (\text { Advertising })_{i, t}+b_{2} \text { Sent }_{t}+b_{3} \ln \left({\text { Advertising })_{i, t}} \text { Sent }_{t}\right. \\
& +b_{4} \text { Contr }_{t}+b_{5} \ln (\text { Advertising })_{i, t} x \text { Contr }_{t}+b_{6} \text { ICS }_{t} \\
& +b_{7} \ln (\text { Advertising })_{i, t} x \text { ICS }_{t}+c_{1} \text { Herf }_{i, t}+c_{2} \text { IndGrowt }_{i, t} \\
& +c_{3} \ln (\text { Capex })_{i, t}+c_{4} \ln (1+R \& D)_{i, t}+\text { Firm Fixed Effects }+\epsilon_{i, t}
\end{aligned}
$$


The dependent variable is the natural log of operating profits in year $t+1$. The coefficient on $\ln$ (Advertising), $b_{1}$, captures the effectiveness of advertising. Of greater interest for us is the coefficient on the interaction variable, $\ln$ (Advertising) $\mathrm{x}$ Sent, which indicates how the effectiveness of advertising varies with sentiment. A negative value for the coefficient, $b_{3}$, would indicate that that the average advertising dollars are more (less) effective in increasing profits during low (high) sentiment periods. We continue to add other control variables that may affect profits such as capital expenditure and $R \& D$, as well as firm fixed effects to account for unobservable differences across firms.

In Table 7, we report the estimates of Equation (7). As expected, the coefficient on In(Advertising) is positive indicating that greater spending on advertising is associated with greater profits. More importantly, the coefficient of the interaction term, In(Advertising) $\mathrm{x}$ Sent, is negative and statistically significant, hence, the effectiveness of advertising indeed varies over time with sentiment and is greater (lower) during low (high) sentiment periods.

\section{$<$ Insert Table 7 about here >}

\section{Contribution and implications}

Our research makes a significant conceptual contribution to the literature that explores the interplay between firms' marketing decisions and conditions in the stock market. While much of this literature examines the impact of marketing decisions on stock prices (Aksoy et al., 2008; Anderson, Fornell, \& Lehmann, 1994; Anderson, Fornell, \& Mazvancheryl, 2004), we extend this research by showing that stock market events can also have a significant influence on marketing decisions (Chakravarty \& Grewal, 2011; Mizik, 2010). Specifically, we show that investor sentiment in the stock market induces marketing managers to change the level of their advertising expenditures. We show that such changes in marketing expenditures are not 
associated with substantial gains in profits. Marketing managers can gain by recognizing these heuristics when making decisions about advertising expenditures.

We also show that investor sentiment has a unique influence on marketing decisionmaking different from that of overall economic conditions, thus extending research by Steenkamp and Fang (2011) and Srinivasan et al. (2011). While these prior studies focus on macroeconomic conditions such as contractions and recessions, this study shows that sentiment in financial markets also influences managers’ decisions. Marketing managers should pay attention to stock market investor sentiment and not just macroeconomic conditions when assessing the extent and effectiveness of advertising expenditures. In fact, marketing managers may also consider investor sentiment when making other marketing expenditure decisions, such as for $R \& D$, hiring sales forces where appropriate, and so on.

We also make an important conceptual contribution to the literature that focusses on the affordability method of advertising budgeting (e.g., Joseph \& Richardson, 2002; Tellis, 1998). Much of this literature has viewed and operationalized the notion of affordability by looking at the availability of internally generated funds, such as profits and cash flows. The findings in our study suggest this may only provide an incomplete picture. Researchers need to also consider the conditions in the financial markets and firms' access to external funds to properly assess the resources available to managers.

Besides these important conceptual contributions, our research can also help marketing managers and investors gain a better understanding of the factors influencing managerial decision-making on advertising expenditure, which accounts for a major portion of marketing spends for most companies, especially in consumer businesses. It can also help perceptive marketing managers improve the efficiency of their advertising expenditure. For example, our finding that firms in general cut their advertising budgets during low sentiment periods offers 
an opportunity to managers who are ready to go against the crowd. Low advertising by others means less competitive clutter and better recall and recognition by consumers for companies that maintain or increase their advertising during such times. Similarly, a general decline in advertising could give managers the opportunity to extract better deals with advertising agencies during low sentiment periods.

Our results caution marketing managers to prepare for the possibility that external funding conditions might force them to cut their advertising budgets precisely when these may be most effective in generating additional sales and enhancing the firms' profits. Any untimely cuts in marketing expenditure due to a sudden worsening of sentiment in the financial markets may expose a firm to delays in the launch of new products or advertising campaigns, which, in turn, may have an adverse impact on brand image and customer loyalty in the long run, with potentially disastrous consequences for the firm's bottom line. In fact, the adverse impact of such cuts in advertising spends may be even worse if a period of negative investor sentiment coincides with or is followed by a period of positive consumer sentiment, because having cut their advertising expenditure in the previous period, the firms may not be in a position to capitalize on the buoyancy in the demand for their products and services in the subsequent period that may be triggered by the rise in consumer sentiment. ${ }^{10}$

\footnotetext{
${ }^{10}$ There are a number of years in our sample where investor sentiment is below its time series mean whereas consumer sentiment is above its time series mean. Some of the years that stand out in this regard are 1972, 1977, 2002 and 2003. These are the years in which investor sentiment was less than -0.5 (i.e., more than 0.5 standard deviation below its mean of zero), but consumer sentiment was significantly above its mean of 85 . To illustrate our point, we pick the year 2002 and examine the behavior of firms in the industry 'Food and Kindred Products' (SIC code=20). The industry has 21 firms in 2002 in our sample. We note that the five firms who decided to cut their advertising the most (including Sara Lee Corporation and Heinz), by an average of 62\%, experience a decline in their average operating profits of $6 \%$ over two-year period of 2002 and 2003. In contrast, the five firms who decided to increase their advertising the most (including Dean Foods and Del Monte), by an average of $121 \%$, experience an increase in average operating profits of $34 \%$ over the same period. Thus, the importance of increasing advertising during periods when investor sentiment is low but consumer sentiment is high.
} 
Conversely, our finding that firms in general increase their advertising budgets during high sentiment periods may also offer an opportunity to some marketing managers. The easier access to funding for their advertising budgets does not always imply that managers should spend more on advertising. Higher advertising by all the players in the market would only result in more competitive clutter with lower recall and recognition by consumers.

Similarly, a general increase in advertising could force managers to enter less favorable deals with advertising agencies during high sentiment periods. Managers could therefore consider whether it may be better to focus on their real needs, such as understanding changes in their customers' needs through more consumer research and investing in developing new products that satisfy these changing needs, which would give these firms a stronger competitive advantage rather than simply spending more money on advertising. This would be especially true if a period of positive investor sentiment coincides with negative consumer sentiment, which may also lead to sub-optimal results because the negative consumer sentiment would not allow the firms to generate additional consumer demand to justify their high advertising expenditure in response to positive investor sentiment. Hence, marketing managers will be well advised to keep an eye on both investor and consumer sentiments to ensure that their advertising budgets are not out of sync with either of these.

Our findings also show that firms are more prone to fluctuations in their advertising spends in reaction to investor sentiment in the stock market when they are more financially constrained. This is an important finding for marketing managers whose firms face financial constraints because it warns them of their greater susceptibility. Finally, by showing another channel through which investor sentiment in the financial market distorts real managerial decisions, our findings also imply that financial market regulators should play a more active role in curbing extreme swings in sentiment, not only due to its direct impact on stock markets, but also its indirect effect on the real economy and firm performance. 


\section{Limitations and future research}

Our research is subject to a few limitations that future research can consider. First, before AcSEC issued the SOP 93-7 rule in December 1993, firms had considerable flexibility in deciding how much of their advertising expenditure to show as expenses and how much to capitalize and show as an asset. Because our study uses longitudinal data to explore the impact of sentiment on advertising expenditure over time, differences in the timing of when firms report their advertising expenditure after it is incurred can introduce noise into our empirical analysis. However, we expect only a minimal impact from any such noise because we use a large dataset (42,192 firm-year observations) over a long period (1971-2010).

Second, some researchers argue that relative market share is a better indicator of marketing performance because it shows how much better a firm is doing compared to its competitors, unlike absolute market share, which only represents how well a firm is doing (Mitchell \& Singh, 1993). However, in this study, we focus on investor sentiment, which affects the marketing decisions and performance of all firms. We thus operationalize marketing effectiveness by looking at the impact of advertising on profits at an aggregate level, in effect looking at how the whole profit pie increases due to more advertising by an average firm. Future researchers should take notice of this distinction and include the appropriate role of market share in their studies.

Third, we study the impact of investor sentiment on the advertising expenditure, but marketing covers a broader range of activities, such as expenditure on the sales force, promotional expenses, and new product development. Future research could therefore extend our work by exploring the impact of investor sentiment on managerial decision-making in these other domains. Fourth, our sample period does not cover recent years after 2010 . Finally, we consider financial constraints as a mediator in the relationship between investor 
sentiment in the stock market and advertising decisions. We acknowledge that several potential moderators exist, such as industry and corporate governance differences that could affect the relationship. These and other issues provide fruitful avenues for future research.

\section{References}

Aaker, D. A., \& Carman, J. M. (1982). Are You Overadvertising? Journal of Advertising Research, 22(4), 57-70.

Aksoy, L., Cooil, B., Groening, C., Keiningham, T. L., \& Yalçın, A. (2008). The long-term stock market valuation of customer satisfaction. Journal of Marketing, 72(4), 105-122.

Albers, S. (2012). Optimizable and implementable aggregate response modeling for marketing decision support. International Journal of Research in Marketing, 29(2), 111-122.

Anderson, E. W., Fornell, C., \& Lehmann, D. R. (1994). Customer satisfaction, market share, and profitability: Findings from Sweden. Journal of Marketing, 58(July), 53-66.

Anderson, E. W., Fornell, C., \& Mazvancheryl, S. K. (2004). Customer satisfaction and shareholder value. Journal of Marketing, 68(October), 172-185.

Baker, M., Stein, J., \& Wurgler, J. (2003). When does the market matter? Stock prices and the investment of equity-dependent firms. Quarterly Journal of Economics, 118(3), 969-1005.

Baker, M., \& Wurgler, J. (2006). Investor sentiment and the cross-section of stock returns. Journal of Finance, 61(4), 1645-1680.

Baker, M., \& Wurgler, J. (2007). Investor sentiment in the stock market. Journal of Economic Perspectives, 21(2), 129-152.

Baker, M., \& Wurgler, J. (2012). Behavioral corporate finance: An updated survey. In G. M. Constantinides, M. Harris \& R. M. Stulz (Eds.), Handbook of the Economics of Finance (Vol. 2): Elsevier Press.

Barberis, N., \& Thaler, R. (2003). A survey of behavioral finance. Handbook of the Economics and Finance, 1(B), 1053-1128.

Batra, R. (2009). Advertising Management, 5/e: Pearson Education India.

Baum, C., Schaffer, M., \& Stillman, S. (2003). Instrumental variables and GMM: Estimations and testing. The Stata Journal, 3(1), 1-31.

Belch, G. E., Belch, M. A., Kerr, G. F., \& Powell, I. (2008). Advertising and promotion: An integrated marketing communications perspective. Sydney: McGraw-Hill. 
Blasko, V. J., \& Patti, C. H. (1984). The Advertising Budgeting Practices of Industrial Marketers. Journal of Marketing, 48(4), 104-110.

Chakravarty, A., \& Grewal, R. (2011). The Stock market in the driver's seat! Implications for R\&D and marketing. Management Science, 57(9), 1594-1609.

Chirinko, R. S., \& Schaller, H. (2001). Business fixed Investment and 'bubbles': The Japanese case. American Economic Review, 91(3), 663-680.

Davidson, R., \& MacKinnon, J. (1993). Estimation and inference in econometrics, Oxford University Press.

Deleersnyder, B., Dekimpe, M. G., Steenkamp, J. B. E., \& Leeflang, P. S. (2009). The role of national culture in advertising's sensitivity to business cycles: An investigation across continents. Journal of Marketing Research, 46(5), 623-636.

Dean, J. (1951). How much to spend on advertising. Harvard Business Review, 29(1), 65-74.

Dong, M. (2010). Mergers and Acquisitions. In H. K. Baker \& J. Nofsinger (Eds.), Behavioral Finance. Hoboken, NJ: Wiley.

Erickson, G., \& Jacobson, R. (1992). Gaining comparative advantage through discretionary expenditures: The returns to R\&D and advertising. Management Science, 38(9), 12641279.

Fama, E. F. (1970). Efficient capital markets: A review of theory and empirical work. The Journal of Finance, 25(2), 383-417.

Fischer, M., \& Himme, A. (2016). The financial brand value chain: How brand investments contribute to the financial health of firms. International Journal of Research in Marketing, 34(1), 137-153.

Frankenberger, K. D., \& Graham, R. C. (2003). Should firms increase advertising expenditures during recessions? Marketing Science Institute Report, (03-003), 65-85.

Gervais, S. (2010). Capital Budgeting and Other Investment Decisions. In H. K. Baker \& J. Nofsinger (Eds.), Behavioral Finance. Hoboken, NJ: Wiley.

Hadlock, C. J., \& Pierce, J. R. (2010). New evidence on measuring financial constraints: Moving beyond the KZ index. Review of Financial Studies, 23(5), 1909-1940.

Hanssens, D. M., Wang, F., \& Zhang, X.-P. (2016). Performance growth and opportunistic marketing spending. International Journal of Research in Marketing, 33(4), 711-724.

Hodrick, R. J., \& Prescott, E. C. (1997). Postwar US business cycles: an empirical investigation. Journal of Money, credit, and Banking, 29(1), 1-16.

Hribar, P., \& Mcinnis, J. (2012). Investor sentiment and analysts' earnings forecast errors. Management Science, 58(2), 293-307.

Jones, J. P. (1990). Ad spending: maintaining market share. Harvard Business Review, 68(1), 38-42. 
Joseph, K., \& Richardson, V. J. (2002). Free cash flow, agency costs, and the affordability method of advertising budgeting. Journal of Marketing, 66(1), 94-107.

Kamber, T. (2002). The brand manager's dilemma: Understanding how advertising expenditures affect sales growth during a recession. Journal of Brand Management, 10(2), 106-120.

Lamont, O., \& Stein, J. (2006). Investor sentiment and corporate finance: Micro and macro. American Economic Review, 96(2), 147-151.

Lee, D. Y. (1994). The impact of firms' risk-taking attitudes on advertising budgets. Journal of Business Research, 31(2-3), 247-256.

Lemmon, M., \& Portniaguina, E. (2006). Consumer confidence and asset prices: Some empirical evidence. Review of Financial Studies, 19(4), 1499-1529.

Lilien, G. L., Kotler, P., \& Moorthy, K. S. (1992). Marketing Models. . NJ, USA: Prentice Hall.

Lodish, L. M., Abraham, M., Kalmenson, S., Livelsberger, J., Lubetkin, B., Richardson, B., \& Stevens, M. E. (1995). How T.V. Advertising Works: A Meta-Analysis of 389 Real World Split Cable T.V. Advertising Experiments. Journal of Marketing Research, 32(2), 125-139.

Luo, M., Jiang, D. X., \& Cai, J. (2014). Investor sentiment, product features, and advertising investment sensitivities. Asia-Pacific Journal of Financial Studies, 43(6), 798-837.

Martín-Herrán, G., McQuitty, S., \& Sigué, S. P. (2012). Offensive versus defensive marketing: What is the optimal spending allocation? International Journal of Research in Marketing, 29(2), 210-219.

McLean, R. D., \& Zhao, M. (2014). The business cycle, investor sentiment, and costly external finance. The Journal of Finance, 69(3), 1377-1409.

Mian, G. M., \& Sankaraguruswamy, S. (2012). Investor sentiment and stock market response to earnings news. Accounting Review, 87(4), 1357-1384.

Mitchell, L. A. (1993). An examination of methods of setting advertising budgets: practice and the literature. European Journal of Marketing, 27(5), 5-21.

Mitchell, W., \& Singh, K. (1993). Death of the lethargic: Effects of expansion into new technical subfields on performance in a firm's base business. Organization Science, 4(2), 152-180.

Mizik, N. (2010). The theory and practice of myopic management. Journal of Marketing Research, 47(4), 594-611.

Mizik, N., \& Jacobson, R. (2007). Myopic marketing management: Evidence of the phenomenon and its long-term performance consequences in the SEO context. Marketing Science, 26(3), 361-379.

Patti, C. H., \& Blasko, V. J. (1981). Budgeting Practices of Big Advertisers. Journal of Advertising Research, 21(6), 23-29. 
Petersen, M. A. (2009). Estimating standard errors in finance panel data sets: Comparing approaches. Review of Financial Studies, 22(1), 435-480.

Polk, C., \& Sapienza, P. (2009). The stock market and corporate investment: A test of catering theory. Review of Financial Studies, 22(1), 187-217.

Prendergast, G., West, D., \& Shi, Y.-Z. (2006). Advertising budgeting methods and processes in China. Journal of Advertising, 35(3), 165-176.

Rasmussen, A. (1952). The determination of advertising expenditure. Journal of Marketing, 16(4), 439-446.

Rossiter, J. R. (2012). Advertising management principles are derived mostly from logic and very little from empirical generalizations. Marketing Theory, 12(2), 103-116.

Shiller, R. (2003). From efficient markets theory to behavioral finance. Journal of Economic Perspectives, 17(1), 83-104.

Shleifer, A. (2003). Inefficient markets: An introduction to behavioral finance. New York: Oxford University Press.

Shleifer, A., \& Vishny, R. (2003). Stock market driven acquisitions. Journal of Financial Economics, 70(3), 295-311.

Simon, H. (1984). Challenges and new research avenues in marketing science. International Journal of Research in Marketing, 1(4), 249-261.

Soberman, D. A. (2009). Marketing agencies, media experts and sales agents: Helping competitive firms improve the effectiveness of marketing. International Journal of Research in Marketing, 26(1), 21-33.

Srinivasan, R., Lilien, G. L., \& Sridhar, S. (2011). Should firms spend more on research and development and advertising during recessions? Journal of Marketing, 75(May), 4965.

Srinivasan, R., Rangaswamy, A., \& Lilien, G. L. (2005). Turning adversity into advantage: Does proactive marketing during a recession pay off? International Journal of Research in Marketing, 22(2), 109-125.

Srinivasan, S., \& Hanssens, D. M. (2009). Marketing and firm value: Metrics, methods, findings, and future directions. Journal of Marketing Research, 46(3), 293-312.

Stambaugh, R., Yu, J., \& Yuan, Y. (2012). The short of it: Investor sentiment and anomalies. Journal of Financial Economics, 104(2), 288-302.

Stambaugh, R., Yu, J., \& Yuan, Y. (2015). Arbitrage asymmetry and the idiosyncratic volatility puzzle. Journal of Finance, 70(5), 1903-1948.

Steenkamp, J.-B. E. M., \& Fang, E. E. (2011). The impact of economic contractions on the effectiveness of R\&D and advertising: Evidence from U.S. companies spanning three decades. Marketing Science, 30(4), 628-645. 
Stein, J. (1996). Rational capital budgeting in an irrational world. Journal of Business, 69(4), 429-455.

Tellis, G. J. (1998). Advertising and Sales Promotion Strategy. Reading, MA: AddisonWesley.

Whited, T., \& Wu, G. (2006). Financial constraints risk. Review of Financial Studies, 19(2), 531-559.

Yu, J., \& Yuan, Y. (2011). Investor sentiment and the mean-variance relation. Journal of Financial Economics, 100(2), 367-381. 
Figure 1

Number of Firms Included in our Sample by Year

This figure reports the number of firms included in our sample for each year. The period spans 1971-2010. We include all firms that report annual advertising expenditure as per COMPUSTAT dataset, subject to the availability of all the controls variables.

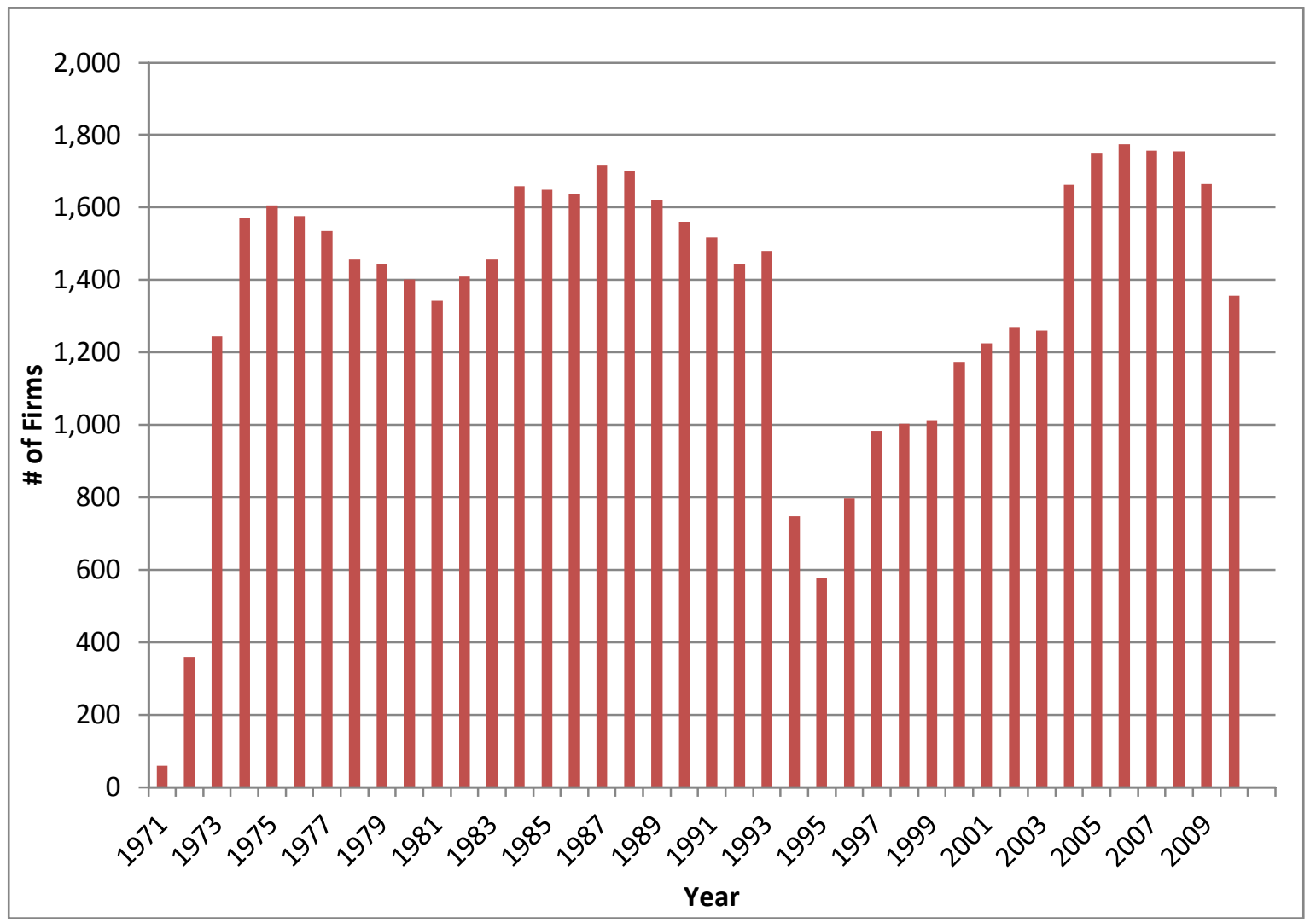


Table 1

Correlations

This table reports the correlations. All variables are described in Appendix.

\begin{tabular}{lcccc}
\hline & Advertising & Sentiment & Contr $(x-1)$ & ICS \\
\hline Advertising & 1 & & & \\
Sentiment & 0.346 & 1 & & \\
Contr $(x-1)$ & 0.336 & 0.002 & 1 & \\
ICS & 0.625 & 0.222 & 0.612 & 1 \\
\hline
\end{tabular}




\section{Table 2}

\section{Summary Statistics}

This table reports the summary statistics for the variables used in this study. Panel A reports the statistics for the annual time series of investor sentiment and other macroeconomics variables that are available at aggregate level. Panel B reports the statistics for advertising intensity and other variables that are available at firm or industry level. The sample spans 40 years over 1971-2010 and includes 54,209 firm-year observations for most variables. All variables are described in Appendix.

\begin{tabular}{lccccc}
\hline Variables & \# of obs. & Mean & $\begin{array}{c}\text { Standard } \\
\text { deviation }\end{array}$ & Minimum & Maximum \\
\hline $\begin{array}{l}\text { Panel A: Macro variables (yearly observations) } \\
\text { Sentiment Variables: }\end{array}$ & & & & & \\
Sent & 40 & -0.05 & 0.92 & -2.24 & 1.79 \\
Control variables: & & & & & \\
Contr & 40 & 1.29 & 2.34 & 0 & 8.79 \\
ICS & 40 & 85.01 & 12.07 & 63.75 & 107.58
\end{tabular}

Panel B: Firm or industry level variables (firm-year observations)

Advertising variables:

\begin{tabular}{lccccc}
\hline $\begin{array}{l}\text { Advertising (in \$ million) } \\
\text { Advertising Intensity (i.e., }\end{array}$ & 54,209 & 34 & 116 & 0.009 & 871 \\
$\begin{array}{l}\text { advertising scaled by avg. sales) } \\
\text { Control and other variables: }\end{array}$ & 54,209 & 0.035 & 0.048 & 0.000 & 0.299 \\
\hline Herf & & & & & \\
IndGrowth & 54,209 & 0.093 & 0.090 & 0.025 & 0.546 \\
Capex (in \$ million) & 54,209 & 0.106 & 0.087 & -0.143 & 0.351 \\
Capex (scaled by avg.sales) & 54,209 & 62 & 209 & 0.010 & 1,566 \\
R\&D (in \$ million) & 54,209 & 0.073 & 0.117 & 0.001 & 0.796 \\
R\&D (scaled by avg.sales) & 54,209 & 18 & 78 & 0.000 & 631 \\
WWIndex & 54,209 & 0.043 & 0.107 & 0.000 & 0.749 \\
SAlndex & 54,209 & -0.235 & 0.116 & -0.510 & 0.025 \\
ExFin (scaled by avg.sales) & 54,209 & -2.997 & 0.764 & -4.687 & -0.976 \\
CF (scaled by avg. sales) & 54,209 & 0.235 & 0.792 & -0.756 & 5.543 \\
Operating Income after & 54,209 & -0.007 & 0.400 & -2.896 & 0.386 \\
Depreciation (in \$ million) & & & & & \\
\hline
\end{tabular}


Table 3

\section{Average Advertising Intensity across Periods of High and Low Investor Sentiment}

This table reports the average values of advertising intensity for firm-year observations sorted into periods of high and low sentiment. The sample consists of 54,209 firm-year observations over the period 1971-2010. High sentiment periods are those when sentiment is above the mean, whereas low sentiment periods are those when sentiment is below the mean. The $t$-statistic reported in parentheses in the last row is based on firm- and yearclustered standard errors (in order to correct for the firm- and year-related autocorrelations and heteroscedasticity). $* * *, * *$ and $*$ represent the $1 \%, 5 \%$ and $10 \%$ significance levels, respectively.

\begin{tabular}{|c|c|c|}
\hline & & Advertising (scaled by avg. sales) \\
\hline Sentiment & \# of Firm-Year Obs. & Avg \\
\hline High $($ Sent $>0)$ & 20,543 & 0.038 \\
\hline Low $($ Sent < 0) & 21,649 & 0.032 \\
\hline $\begin{array}{l}\text { High - Low } \\
\text { (t-statistic) }\end{array}$ & & $\begin{array}{c}0.006^{\star \star *} \\
(14.76)\end{array}$ \\
\hline
\end{tabular}




\section{Table 4}

\section{Investor Sentiment and Advertising Expenditure - Regression Analysis}

This table reports the estimates of Equation (4). Variable definitions are provided in Appendix. The $t$-statistics are reported in parentheses and are based on standard errors that are clustered by year. We do not report the intercepts as the inclusion of firm fixed effects in the model make them difficult to interpret. ***, ** and * represent the $1 \%$, $5 \%$ and $10 \%$ significance levels, respectively.

\begin{tabular}{|c|c|c|c|}
\hline \multirow[b]{3}{*}{ Explanatory Variables } & \multicolumn{3}{|c|}{ Dependent Variable: In(Advertising Intensity) } \\
\hline & & $F C=W W I n d e x$ & $F C=$ SAlndex \\
\hline & (1) & $(2)$ & (3) \\
\hline \multirow[t]{2}{*}{ In(Advertising Intensity) ${ }_{t-1}$} & $0.590^{\star \star \star}$ & $0.589 * \star \star$ & $0.584^{\star \star \star}$ \\
\hline & $(36.10)$ & $(36.13)$ & $(36.26)$ \\
\hline \multirow[t]{2}{*}{ Sent } & $0.017^{\star \star \star}$ & $0.036^{\star \star \star}$ & $0.068^{\star \star \star}$ \\
\hline & $(2.72)$ & $(2.95)$ & $(3.16)$ \\
\hline \multirow[t]{2}{*}{ Sent $\times$ FC } & & $0.072^{\star *}$ & $0.015^{\star \star}$ \\
\hline & & $(2.05)$ & $(2.38)$ \\
\hline \multirow[t]{2}{*}{$F C$} & & 0.205 & $0.107^{*}$ \\
\hline & & $(0.68)$ & $(1.98)$ \\
\hline \multirow[t]{2}{*}{ Contr } & -0.004 & -0.004 & -0.007 \\
\hline & $(-0.93)$ & $(-0.58)$ & $(-0.73)$ \\
\hline \multirow[t]{2}{*}{ Contr $\times$ FC } & & -0.001 & -0.001 \\
\hline & & $(-0.06)$ & $(-0.35)$ \\
\hline \multirow[t]{2}{*}{ ICS } & $0.002^{\star \star \star}$ & $0.002^{*}$ & 0.001 \\
\hline & $(4.09)$ & $(1.70)$ & $(0.38)$ \\
\hline \multirow[t]{2}{*}{$I C S \times F C$} & & 0.000 & -0.000 \\
\hline & & $(0.01)$ & $(-0.62)$ \\
\hline \multirow[t]{2}{*}{ Herf } & 0.091 & 0.073 & 0.035 \\
\hline & $(1.27)$ & $(1.05)$ & $(0.52)$ \\
\hline \multirow[t]{2}{*}{ IndGrowth } & $0.214^{\star \star \star}$ & $0.186^{\star *}$ & $0.154^{\star \star}$ \\
\hline & $(2.96)$ & $(2.45)$ & $(2.08)$ \\
\hline \multirow[t]{2}{*}{ Capex/Sales } & $0.783^{\star \star \star}$ & $0.785^{\star \star \star}$ & $0.763^{\star \star \star}$ \\
\hline & $(12.05)$ & $(12.19)$ & (11.94) \\
\hline \multirow[t]{2}{*}{$\ln (1+R \& D /$ Sales $)$} & $0.928^{\star \star \star}$ & $0.915^{\star \star \star}$ & $0.937^{\star \star \star}$ \\
\hline & $(7.25)$ & $(7.17)$ & $(7.42)$ \\
\hline Fixed effects & Firm & Firm & Firm \\
\hline Cluster by & Year & Year & Year \\
\hline \# of firm-year obs. & 49,387 & 49,387 & 49,387 \\
\hline Adjusted R-squared & 0.871 & 0.871 & 0.871 \\
\hline
\end{tabular}


Table 5

External Financing and Advertising Expenditure - Regression Analysis

This table reports the estimates of Equation (5). Variable definitions are provided in Appendix. The $t$-statistics are reported in parentheses and are based on standard errors that are clustered by year. We do not report the intercepts as the inclusion of firm fixed effects in the model make them difficult to interpret. ***, ** and * represent the $1 \%$, $5 \%$ and $10 \%$ significance levels, respectively.

\begin{tabular}{|c|c|c|c|}
\hline \multirow[b]{3}{*}{ Explanatory Variables } & \multicolumn{3}{|c|}{ Dependent Variable: In(Advertising Intensity) } \\
\hline & \multirow[b]{2}{*}{ (1) } & \multirow{2}{*}{$\frac{F C=W W I n d e x}{(2)}$} & \multirow{2}{*}{$\begin{array}{c}\mathrm{FC}=\text { SAlndex } \\
(3)\end{array}$} \\
\hline & & & \\
\hline \multirow{2}{*}{ In(Advertising Intensity) ${ }_{t-1}$} & $0.593^{\star \star \star}$ & $0.592^{\star \star *}$ & $0.589^{\star \star \star}$ \\
\hline & $(36.70)$ & $(36.83)$ & $(36.78)$ \\
\hline \multirow[t]{2}{*}{ ExFin } & $0.072^{\star \star \star}$ & $0.139^{\star \star \star}$ & $0.210^{\star \star \star}$ \\
\hline & $(7.63)$ & $(8.18)$ & $(6.69)$ \\
\hline \multirow[t]{2}{*}{ ExFin $x F C$} & & $0.249^{\star \star \star}$ & $0.045^{\star \star \star}$ \\
\hline & & $(5.64)$ & $(4.93)$ \\
\hline \multirow[t]{2}{*}{$F C$} & & 0.119 & $0.052^{\star *}$ \\
\hline & & (1.10) & $(2.70)$ \\
\hline \multirow[t]{2}{*}{ Herf } & 0.055 & 0.036 & 0.005 \\
\hline & $(0.86)$ & $(0.58)$ & $(0.08)$ \\
\hline \multirow[t]{2}{*}{ IndGrowth } & $0.325^{\star \star \star}$ & $0.313^{\star \star \star}$ & $0.301^{\star \star *}$ \\
\hline & $(3.16)$ & $(3.05)$ & $(3.11)$ \\
\hline Capex/Sales & $0.659^{* * *}$ & $0.620^{\star \star \star}$ & $0.615^{\star \star *}$ \\
\hline \multirow{3}{*}{$\ln (1+R \& D /$ Sales $)$} & $(10.52)$ & $(10.05)$ & $(10.25)$ \\
\hline & $0.745^{\star \star \star}$ & $0.615^{\star \star \star}$ & $0.654^{\star \star \star}$ \\
\hline & $(6.30)$ & $(5.21)$ & $(5.56)$ \\
\hline Fixed effects & Firm & Firm & Firm \\
\hline Cluster by & Year & Year & Year \\
\hline \# of firm-year obs. & 49,387 & 49,387 & 49,387 \\
\hline Adjusted R-squared & 0.871 & 0.872 & 0.872 \\
\hline
\end{tabular}




\section{Table 6}

\section{Investor Sentiment and External Financing - Regression Analysis}

This table reports the estimates of Equation (6). Variable definitions are provided in Appendix. The $t$-statistics are reported in parentheses and are based on standard errors that are clustered by year. We do not report the intercepts as the inclusion of firm fixed effects in the model make them difficult to interpret. ***, ** and * represent the $1 \%$, $5 \%$ and $10 \%$ significance levels, respectively.

\begin{tabular}{|c|c|c|c|}
\hline \multirow[b]{3}{*}{ Explanatory Variables } & \multicolumn{3}{|c|}{ Dependent Variable: ExFin } \\
\hline & & $\mathrm{FC}=\mathrm{WWIndex}$ & $\mathrm{FC}=$ SAlndex \\
\hline & $(1)$ & $(2)$ & $(3)$ \\
\hline \multirow[t]{2}{*}{ Sent } & 0.005 & 0.015 & $0.047^{\star \star}$ \\
\hline & $(0.81)$ & $(1.33)$ & $(2.13)$ \\
\hline \multirow[t]{2}{*}{ Sent $x F C$} & & $0.077^{\star *}$ & $0.015^{\star \star}$ \\
\hline & & $(1.99)$ & $(2.50)$ \\
\hline \multirow[t]{2}{*}{$F C$} & & 1.078 & 0.140 \\
\hline & & $(0.94)$ & $(1.31)$ \\
\hline \multirow[t]{2}{*}{ Contr } & 0.002 & -0.013 & -0.022 \\
\hline & $(0.44)$ & $(-1.37)$ & $(-1.52)$ \\
\hline \multirow[t]{2}{*}{ Contr $x$ FC } & & -0.065 & -0.008 \\
\hline & & $(-1.33)$ & $(-1.52)$ \\
\hline \multirow[t]{2}{*}{ ICS } & $0.003^{* *}$ & -0.004 & -0.004 \\
\hline & $(2.22)$ & $(-1.39)$ & $(-1.12)$ \\
\hline \multirow[t]{2}{*}{$I C S \times F C$} & & $-0.025^{\star}$ & $-0.002^{\star}$ \\
\hline & & $(-2.02)$ & $(-1.85)$ \\
\hline \multirow[t]{2}{*}{ Herf } & 0.058 & 0.131 & 0.096 \\
\hline & $(0.73)$ & $(1.51)$ & $(1.15)$ \\
\hline \multirow[t]{2}{*}{ IndGrowth } & $0.348^{\star \star \star}$ & $0.477^{\star * *}$ & $0.384^{\star * *}$ \\
\hline & $(2.79)$ & (3.61) & $(2.95)$ \\
\hline \multirow[t]{2}{*}{ Capex/Sales } & $2.093^{\star \star \star}$ & $2.072^{\star \star \star}$ & $2.104^{\star \star \star}$ \\
\hline & $(13.61)$ & $(13.77)$ & $(13.60)$ \\
\hline \multirow[t]{2}{*}{$\ln (1+R \& D /$ Sales $)$} & $2.842^{\star \star \star}$ & $2.923^{\star \star \star}$ & $2.845^{\star \star \star}$ \\
\hline & $(9.16)$ & $(9.44)$ & $(9.22)$ \\
\hline Fixed effects & Firm & Firm & Firm \\
\hline Cluster by & Year & Year & Year \\
\hline \# of firm-year obs. & 54,209 & 54,209 & 42,191 \\
\hline Adjusted R-squared & 0.526 & 0.530 & 0.460 \\
\hline
\end{tabular}


Table 7

\section{Investor Sentiment and Advertising Effectiveness - Regression Analysis}

This table reports the estimates of Equation (7). Variable definitions are provided in Appendix. The $t$-statistics are reported in parentheses and are based on standard errors that are clustered by year. We do not report the intercepts as the inclusion of firm fixed effects in the model make them difficult to interpret. ***, ** and * represent the $1 \%$, $5 \%$ and $10 \%$ significance levels, respectively.

\begin{tabular}{|c|c|}
\hline Explanatory Variables & Dependent Variable:: In(Operating Income) ${ }_{t+1}$ \\
\hline \multirow[t]{2}{*}{ In(Advertising) } & $0.220^{\star \star \star}$ \\
\hline & (5.80) \\
\hline \multirow[t]{2}{*}{ Sent } & -0.019 \\
\hline & $(-0.88)$ \\
\hline \multirow[t]{2}{*}{ In(Advertising) $\times$ Sent } & $-0.013^{\star \star \star}$ \\
\hline & $(-2.85)$ \\
\hline Contr & $\begin{array}{l}0.003 \\
(0.28)\end{array}$ \\
\hline \multirow[t]{2}{*}{ In(Advertising) $\times$ Contr } & $0.003^{*}$ \\
\hline & $(1.85)$ \\
\hline ICS & $\begin{array}{l}0.000 \\
(0.01)\end{array}$ \\
\hline \multirow[t]{2}{*}{$\operatorname{In}$ (Advertising) $\times$ ICS } & 0.001 \\
\hline & (1.66) \\
\hline \multirow[t]{2}{*}{ Herf } & -0.262 \\
\hline & $(-1.25)$ \\
\hline \multirow[t]{2}{*}{ IndGrowth } & -0.184 \\
\hline & $(-1.06)$ \\
\hline In(Capex) & $\begin{array}{c}0.244^{\star \star *} \\
(20.88)\end{array}$ \\
\hline $\ln (1+R \& D)$ & $\begin{array}{c}0.165^{\star \star \star} \\
(9.75)\end{array}$ \\
\hline Fixed Effects & Firm \\
\hline Cluster by & Year \\
\hline \# of firm-year obs. & 42,266 \\
\hline Adjusted R-squared & 0.834 \\
\hline
\end{tabular}




\section{Appendix A}

\section{Description of the Variables}

This appendix provides detailed description of all the variables used in the paper. The two sentiment variables—ICS and Sent-are computed at the market-level for each year. The sources of these data are noted in the table. Herfindahl-Hirschman index, Industry growth and Industry sales growth are computed at the level of SIC two-digit industry. All remaining variables are computed at firm level for each year. The data for the firm- and industry-level variables come from S\&P COMPUSTAT Annual file.

\begin{tabular}{|c|c|c|}
\hline Variable Name & Symbol & Description \\
\hline \multicolumn{3}{|c|}{ A1: Variables employed in our study } \\
\hline Advertising & Advertising & Dollar amount of annual advertising expenditure (COMPUSTAT item 'xad') \\
\hline Advertising intensity & $\begin{array}{l}\text { Advertising } \\
\text { Intensity }\end{array}$ & $\begin{array}{l}\text { Annual advertising expenditure divided by the average sales in the contemporaneous and preceding years, as } \\
\text { depicted in Equation (1) }\end{array}$ \\
\hline Capital expenditure & Capex & Annual capital expenditure (COMPUSTAT item ‘capx’) \\
\hline Economic recession & Contr & $\begin{array}{l}\text { A measure of economic recession constructed by Steenkamp and Fang (2011). We closely follow the procedure } \\
\text { in Steenkamp and Fang (2011) to construct this measure using the filter and the cyclical component of GDP } \\
\text { (Hodrick \& Prescott, 1997). Specifically, Contr takes the value of zero when the economy is growing at or above } \\
\text { its long-term trend, but equals the magnitude of the decline in the cyclical component of GDP when the economy } \\
\text { is in recession. }\end{array}$ \\
\hline External finance & ExFin & $\begin{array}{l}\text { External financing of firm in year } t \text {, computed by taking the change in total assets (COMPUSTAT item 'at') from } \\
\text { year } t-1 \text { to } t \text {, and subtracting from it the change in retained earnings (COMPUSTAT item 're') over the same } \\
\text { period. This definition encompasses all types of external financing, including net new stock issue, net new bond } \\
\text { issues, short- and long-term borrowing from banks, and so on. We scale external financing by average sales in } \\
\text { year } t-1 \text { and } t \text { to make it comparable to the other firm-level variables we report. }\end{array}$ \\
\hline Financial constraints & FC & $\begin{array}{l}\text { Financial constraints, which alternately is measured by WW Index and SA index. It is computed for each firm-for } \\
\text { each year. }\end{array}$ \\
\hline $\begin{array}{l}\text { Herfindahl- } \\
\text { Hirschman index }\end{array}$ & Herf & $\begin{array}{l}\text { Herfindahl-Hirschman index is a commonly used measure of industry concentration and competitiveness. It is } \\
\text { calculated by squaring the market share of each firm competing in an SIC 2-digit industry, and then summing the } \\
\text { resulting numbers across all firms in the industry. The higher the index, the more concentrated, and less } \\
\text { competitive, the industry. Theoretically, the value of the index can range from close to zero (extremely } \\
\text { competitive industry) to 10,000 (complete monopoly-only one firm operating in the industry). }\end{array}$ \\
\hline $\begin{array}{l}\text { Index of consumer } \\
\text { sentiment }\end{array}$ & ICS & $\begin{array}{l}\text { Index of consumer sentiment reported by University of Michigan. It is compiled based on telephone interviews of } \\
\text { US households, and reflects consumer attitudes towards economy and planned purchases. ICS is now available on } \\
\text { a monthly frequency, but it was available on a quarterly basis before } 1978 \text {. We therefore use its quarterly } \\
\text { observations over our entire sample period, and take the average of the four calendar quarters to compute the } \\
\text { annual value of the index. The data can be downloaded from http://www.sca.isr.umich.edu/tables.html. }\end{array}$ \\
\hline
\end{tabular}




\begin{tabular}{|c|c|c|}
\hline Variable Name & Symbol & Description \\
\hline Industry growth & IndGrowth & $\begin{array}{l}\text { Average growth rate of sales for an SIC 2-digit industry. We first compute the sales growth for each firm by } \\
\text { taking the log difference in sales (COMPUSTAT item 'sale') over successive years, and then take the mean } \\
\text { of the individual firms' growth rates in the industry. }\end{array}$ \\
\hline Investor sentiment index & Sent & $\begin{array}{l}\text { Index of investor sentiment in the stock market developed by Baker and Wurgler (2006), and downloaded } \\
\text { from the web site of Jeffrey Wurgler (http://people.stern.nyu.edu/jwurgler/). The index combines six } \\
\text { individual proxies of investor sentiment, namely closed-end fund discount, NYSE share turnover, number of } \\
\text { IPOs, first day returns on IPOs, share of equity issues in total debt and equity issues, and dividend premium } \\
\text { (the log difference of the average market-to-book ratio of payers and non-payers). To isolate investor } \\
\text { sentiment from economic fundamentals, each of these six proxies is first regressed on several } \\
\text { macroeconomic variables. The first principal component of the residuals of these six regressions constitutes } \\
\text { the investor sentiment index, standardized to yield a mean of zero and a standard deviation of one. }\end{array}$ \\
\hline Operating income & $\begin{array}{l}\text { Operating } \\
\text { Income }\end{array}$ & Operating income after depreciation (COMPUSTAT item ‘oiadp’) \\
\hline $\begin{array}{l}\text { Research and development } \\
\text { expenditure }\end{array}$ & $R \& D$ & Annual research and development expenditure (COMPUSTAT item 'xrd’) \\
\hline Sales & Sales & Annual net sales (COMPUSTAT item ‘sale’) \\
\hline \multicolumn{3}{|c|}{ A2: Variables related to WW Index: } \\
\hline Cash flows & $C F$ & $\begin{array}{l}\text { Cash flows computed as net income before extraordinary items plus depreciation and amortization expense } \\
\text { (COMPUSTAT item 'ib' + COMPUSTAT item 'dp') }\end{array}$ \\
\hline Dummy for dividends paid & DIVPOS & $\begin{array}{l}\text { DIVPOS is a dummy variable that takes the value of one if the firm pays any dividend on preferred or } \\
\text { common stocks, and zero otherwise. Specifically, DIVPOS=1 if COMPUSTAT item 'dvc' or 'dvp' }>0 \text {; and } \\
\text { otherwise DIVPOS }=0 \text { ) }\end{array}$ \\
\hline Firms sales growth & SG & Growth in a firm’s sales, computed by subtracting one from sales in year $t$ divided by sales in year $t-1$. \\
\hline Industry sales growth & ISG & $\begin{array}{l}\text { Average sales growth of all the firms in the industry, based on SIC 3-digit industry classification. Sales } \\
\text { growth is first computed for each firm by subtracting one from sales in year } t \text { divided by sales in year } t-1 \text {. } \\
\text { The mean across all firms in the industry is then used to represent the industry growth. }\end{array}$ \\
\hline $\begin{array}{l}\text { Long term debt to total } \\
\text { assets }\end{array}$ & LTD & Ratio of long-term debt (COMPUSTAT item 'dltt') to book value of total assets (COMPUSTAT item 'at'). \\
\hline Total assets & TA & Natural log of book value of total assets (COMPUSTAT item 'at') \\
\hline $\begin{array}{l}\text { Whited and } \mathrm{Wu}(2006) \\
\text { Index }\end{array}$ & WWIndex & $\begin{array}{l}\text { Index of financial constraints constructed by Whited and Wu (2006). It is based on six inputs, namely cash } \\
\text { flows, dividends, book value of assets, firm's sales growth, ratio of long-term debt to assets, and industry } \\
\text { sales growth. The computation is based on Equation (2). The weights for the inputs are taken from Whited } \\
\text { and Wu (2006, Equation } 13 \text { \& Table } 1) \text {. }\end{array}$ \\
\hline
\end{tabular}




\begin{tabular}{|l|c|l|}
\hline Variable Name & Symbol & Description \\
\hline A3: Variables related to SA Index: & \multicolumn{2}{|l|}{} \\
\hline Firm age & Age & Number of years since the firm first appears in COMPUSTAT dataset. \\
\hline $\begin{array}{l}\text { Hadlock and Pierce (2010) } \\
\text { Index }\end{array}$ & SAIndex & $\begin{array}{l}\text { Index of financial constraints constructed by Hadlock and Pierce (2010). It is based on two inputs, namely, } \\
\text { inflation-adjusted total assets and firm age. The computation is based on Equation (3). The weights for the } \\
\text { inputs are taken from Hadlock and Pierce (2006, Table 6, Column 2). }\end{array}$ \\
\hline $\begin{array}{l}\text { Total inflation-adjusted } \\
\text { assets }\end{array}$ & ATA & $\begin{array}{l}\text { Natural log of inflation-adjusted total assets (i.e., natural log of COMPUSTAT item 'at' divided by CPI } \\
\text { inflation deflator), as in Hadlock and Pierce (2010). }\end{array}$ \\
\hline
\end{tabular}

